\title{
Sheherazade's Notebook: \\ Editing Textual Dysteleology and Autographic Modernism
}

Critical editions of 'Complete Works' are typically organized in a teleological manner, using each of the author's published works as an endpoint. In addition to this useful tradition, this article suggests a 'dysteleological' approach. The term 'dysteleology', indicating that evolution has no inherent goal, was coined in the years leading up to Modernism. The existence of vestigial organs served as an example to corroborate the 'dysteleological' view. A writer's unused notes may be regarded as similarly 'vestigial'. They are purposeless from a teleological point of view, but they are crucial elements in the study of creative writing processes ('genetic criticism'). These elements have their rightful place in a scholarly edition, and it is therefore necessary to complement a teleological editorial tradition with a 'dysteleological' approach. To corroborate this argument, the article examines works by James Joyce and Samuel Beckett, as well as by less canonical authors such as Raymond Brulez.

Keywords: Editing; Modernism; Dysteleology; Beckett; Joyce

Scholarly editing traditionally tends to focus on establishing critically edited texts and to prioritize an author's published works to arrange her or his 'complete works'. This approach is teleological in the sense that the finished product serves as the main criterion to organize the edition. This teleological approach has served readers well and continues to prove useful in the digital age. But digital editing offers editors opportunities to consider an additional approach, which will be referred to as 'dysteleological'. The proposed editorial model is mainly designed to try to give more prominence to vestigial notes that play an important part in modernist authors' 'autography' in the sense of both H. Porter Abbott's definition of the term as a 'mode of action taken in the moment of writing' ${ }^{1}$ and Nelson Goodman's distinction between allographic and autographic art. $^{2}$ The present article will show how, in addition to a teleological model, a less teleological editorial approach makes clear that, from many modernist writers' point of view, their 'work' did not boil down simply into a canon of products (published texts). They often saw their work as a set of writings that represent an autographic process, sometimes without a clear 'telos'. It takes as its primary material modernist notebooks by both canonical (James Joyce, Samuel Beckett) and non-canonical (Raymond Brulez) writers. This article also argues that the autographic process needs to be edited as well, and the digital medium may be instrumental to realizing this scholarly aim. 


\section{Textual Dysteleology}

Probably the most teleological of all geneses is the Biblical Book of Genesis. As Almuth Grésillon has pointed out in Eléments de critique génétique, a literary genesis usually differs fundamentally from this Biblical story, for the Book of Genesis presents creation as a linear process that leads directly to its end: God's satisfaction. ${ }^{3}$ In this genesis, the human being appears as the pinnacle of creation. But that is only part of the story. For in chapter 6 of the Book of Genesis, God regrets having made the human being: 'And it repented the LORD that he had made man on the earth, and it grieved him at his heart. And the LORD said, I will destroy man whom I have created from the face of the earth; both man, and beast, and the creeping thing, and the fowls of the air; for it repenteth me that I have made them.' (King James Bible, Genesis 6:6) If it had not been for Noah, humanity would have been nothing more than a pentimento in the world's history, according to this Biblical account. In Samuel Beckett's late modernist version of the story, Fin de partie, the Godlike protagonist therefore muses that he should also regret having made Noah: 'Ah Noé, Noé toi aussi il fallait se repentir de t'avoir fait!' (BDMP7, second French typescript, FT2, 43r) ['Ah Noah, Noah, one should also regret having made you!'] ${ }^{4}$

In the run-up to modernism, Charles Darwin presented an alternative to this Biblical story of Genesis. As Gillian Beer notes with regard to literature, Darwin's theory and 'its eschewing of fore-ordained design (its dysteleology) allowed chance to figure as the only sure determinant' in literature after Darwin. ${ }^{5}$ The man who introduced and promoted Darwin's work in Germany was the biologist Ernst Haeckel. He coined the term 'dysteleology' to argue that evolution has no inherent goal. To corroborate his argument, he referred to vestigial organs, for instance the tiny, vestigial hind leg bones buried in muscles toward the tail ends of the boa constrictor that do not seem to have any direct function. They just indicate that these snakes descended from lizards. A writer's unused notes may be regarded as similarly 'vestigial'. They are purposeless from a teleological point of view, but they are crucial elements in the study of creative writing processes ('genetic criticism'). For that reason, we additionally need a less teleological, that is a more 'dysteleological' approach, to edit these elements.

James Joyce's Finnegans Wake notebooks are filled to the brim with examples to illustrate this 'vestigial' quality. Take for instance notebook VI.B.11 (kept at the 
University at Buffalo). Page 50 features 17 lines of notes, only 6 of which are crossed out with a colour crayon (which was Joyce's method of indicating which note he had used to write his drafts). Thus, the first note 'quatuor' is crossed out in red, but the second, 'chimpanzee' is not; neither is its counterpart on line 9: 'humanzee'. On line 13, Joyce wrote the note 'Great Taskmaster's eye'. It is a reference to the sonnet 'On his being arrived at the age of 23' by John Milton, complaining that Time has stolen his 'three and twentieth year' too soon, but then accepting that 'All is [...] as ever in my great taskmaster's eye'. Joyce crossed out the note and used it for a passage on the first page of the so-called 'Guiltless' Copybook, a red-backed notebook, kept at the British Library, dubbed 'Guiltless' because that is the first word on the notebook's opening page (BL-Add 47471b), a passage that eventually became chapter 2 of Finnegans Wake. The protagonist is said to be clearly 'guiltless', for so he declared himself to be, and he was even prepared to declare it 'upon the open bible before the Great Taskmaster's eye':

I am prepared to [...] take my stand (...) upon the monument any hygienic day at this hour and to declare $[\ldots]$ upon the open bible before the Great Taskmaster's eye \& in the presence of the deity my immediate neighbour and my fellows in every corner on this globe in general \& to each living soul acquainted with the British tongue that there is not one tittle of truth in that purest of fabrications. (BL-Add 47471b, 1r) ${ }^{6}$

The passage eventually made it into Finnegans Wake. ${ }^{7}$ But the Milton quotation was part of only a minority of notes that were crossed out on page 50 . The other $65 \%$ of the notes on that page never made it into any of the drafts, let alone into the published text. In this particular example both the 'chimpanzee' and the 'humanzee' were extinct species, so to speak, in the evolution of Joyce's 'work in progress'. Instead of regarding these notes as disjecta of Finnegans Wake, I think we should consider and therefore also edit them as a vestigial but nonetheless integral part of 'Work in Progress'.

'Dysteleology' in this context of textual scholarship may at first sight seem an inappropriate term since, as Daniel Ferrer has shown, any literary project implies a projection into the future and therefore a certain amount of teleology. ${ }^{8}$ But that does not mean that every aspect of the project is purposeful. The 'telos' often shifts during 
the writing process. In Joyce's case there are numerous notes that were originally made with a particular project in mind but eventually ended up elsewhere. For instance, in notebook II.i.2 among the 'Preparatory and Ancillary Merterials' of the 'Joyce Papers 2002' preserved at the National Library of Ireland, Joyce arranged various notes under the chapter headings 'Telemachus', 'Nestor', 'Proteus', 'Calypso', etcetera. Thus, the first note under the heading 'Calypso' on folio $2 \mathrm{v}$ ('cat sees invisible things pass commode', crossed out in blue pencil) was probably meant to be used in the drafts of the 'Calypso' episode of Ulysses (chapter 4), but eventually Joyce apparently decided to shift this 'telos' and use it in the final chapter instead:

I love to hear him falling up the stairs of a morning with the cups rattling on the tray and then play with the cat she rubs up against you for her own sake I wonder has she fleas shes as bad as a woman always licking and lecking but I hate their claws I wonder do they see anything that we cant staring like that when she sits at the top of the stairs (Joyce 1986: 628-9; emphasis added) ${ }^{9}$

The only note under the 'Calypso' heading in the NLI notebook that was not crossed out ('leggy colt') was later copied into another notebook (VI.B.7, p. 235) by Joyce's amanuensis France Raphael. Joyce crossed it out in notebook VI.B.7 (preserved at the University at Buffalo) and eventually the note's original 'telos' shifted from 'Calypso' in Ulysses to a completely different literary project: Finnegans Wake where it appears in Book 2, Chapter 2, as footnote number 5 on page 289: 'Fox him! The leggy colt!' So, although the uncancelled note 'leggy colt' in the NLI notebook was seemingly 'unused', it did have its function in the evolution of Joyce's oeuvre.

Obviously, there are hundreds of other uncancelled notes that never made it into any of Joyce's drafts, let alone into any of his published works. Yet, they also had a function in the genesis, and so the term 'dysteleology' does not mean that the disregarded or unused entries in a notebook do not have a telos or purpose. It simply means that, like the vestigial organs such as the hind legs of the boa constrictor, they had a purpose at some point or at some stage in the evolution of the work. Without those hind legs the boa (as we know it today) might not be what it is; without the vestigial notes the work (as we know it today) might not be what it is. The work-aswe-know-it-today is our generation's idea of a work as it is implied by all the versions we know of. Thus, our idea of Ulysses post-Gabler is different from that of the same 
book before the synoptic edition. It is the editor's job to gather information about the different versions of a literary work for his/her generation of readers in order for them to be able to form their idea of it.

I suggest that it is the editor's job to also offer our generation of readers information about the 'vestigial', 'dysteleological' notes, the disjecta that did not make it into the published text. This requires an editorial approach that is not exclusively textual and therefore 'allographic', but also pays attention to the material and 'autographic' characteristics of particular documents. As I will now argue, this is of particular significance when approaching a modernist text.

\section{Autography}

Fifty years ago, Nelson Goodman made a distinction between allographic and autographic art in the chapter 'The Unfakable' in Languages of Art: 'Let us speak of a work of art as autographic if and only if the distinction between original and forgery of it is significant; or better, if and only if even the most exact duplication of it does not thereby count as genuine. [...] Thus painting is autographic, music nonautographic, or allographic'. ${ }^{10}$ Literature for Goodman, like music, is allographic because it exists in different versions - both in the sense of various editions and in the sense of various draft stages. But in addition to allographic considerations, a particular document, say a writer's notebook, can also have autographic qualities relating to page layout and other bibliographic particularities that may be relevant to literary studies. These autographic qualities require a documentary editorial approach in addition to the allographic textual treatment.

A good example of an allographic approach to a manuscript edition (or manuscript archive) is the James Joyce Digital Archive (JJDA). To structure this 'archive' the editors, Danis Rose and John O'Hanlon, have taken the structure of the published version of the text as a starting point, not unlike the teleological structure of the James Joyce Archive (hereafter abbreviated as $J J A$ ). ${ }^{11}$ The 'Guiltless' copybook (see above) is not reproduced in one volume of the $J J A$; instead, since it contains drafts of various sections of chapters $2,3,4,5,7$ and 8 , the facsimiles have been arranged in four different volumes ( $J J A$ vols. 45, 46, 47 and 48). And because sometimes a page contains parts of different sections, this page had to be reproduced twice or even three times, as in the case of page 30r. The $J J D A$ 's approach is similarly 
teleological. If a reader is interested in, say, the fifth chapter of the first book of Finnegans Wake (the Mamafesta chapter), s/he can have a look at all the versions that preceded (the published version of) that chapter. In the published text, there is a passage about a hen and 'her genesic field'. ${ }^{12}$ The archive offers the preceding textual versions (in the form of transcripts), back until the first typescript. But in the manuscripts, it seems to be gone. ${ }^{13}$ Actually, it should be there, for the words 'her genesic field' occur on folio 61 verso of the so-called 'Guiltless' copybook. The reason why the 'genesic field' does not appear in transcripts of the manuscripts of chapter I.5 in the James Joyce Digital Archive is that it is part of a paragraph that was added while Joyce was preparing a different chapter (Book 1 chapter 7). ${ }^{14}$ To enable readers to explore this interaction between episodes we need a document-oriented approach in addition to the teleological, textual approach.

As this example illustrates, the notebook (the 'Guiltless' copybook) is an ecology of creation in its own right. This creative ecology implies that every item on the page can interact with any other item in the vicinity, and also has a potential impact on the continuation of the writing process. Joyce's awareness of this effect of the text-produced-so-far on the ongoing work in progress is probably the reason why he tried to stay in this creative space for as long as possible: after writing only on the right-hand pages and leaving the versos blank, he started filling the blank versos and even writing in retrograde direction wherever he found some blank space. As a result, it seems important to present the transcripts of the texts in this notebook in a teleological fashion (as in the $J J D A$ ), but also their interaction and the digital facsimiles of the notebook as a creative ecology, respecting and digitally approximating the physical integrity of the material object.

\section{Autographic Modernism, Both Canonical and Non-Canonical}

In itself, the phenomenon of a notebook's creative ecology is of course not an exclusively 'modernist' quality. But many modernist works do thematize this phenomenon rather frequently and to some extent modernist authors themselves have suggested a more documentary and less exclusively textual or teleological editorial approach to their own works. During the first meeting of the AHRC project 'New Modernist Editing', one of the key questions was: what is 'new' about this editing? A genetic perspective can be part of an answer this question, suggesting that new modernist editing takes its cue from many modernists' explicit awareness of their own 
works' creative process, such as Joyce's Finnegans Wake and what James S. Atherton has called the book's 'awareness of itself as a "work in progress". ${ }^{15}$

This awareness is explicit in the sense that numerous modernist works draw attention to their own genesis and emphasize their own artificiality. It should however be noted that this trend is not entirely unique to the modernist period. As Charlotte Guichard recently pointed out, the eighteenth century was an important moment in the appreciation of the creative process as an integral part of the aesthetic experience. ${ }^{16}$ Around the same time, writers such as Laurence Sterne introduced the same selfawareness and revaluation of the ephemeral gesture in literature. But the trend does seem to have become less prominent during the nineteenth century and reemerged towards the end of the nineteenth and the beginning of the twentieth centuries, in works such as Virginia Woolf's To the Lighthouse, James Joyce's A Portrait of the Artist as a Young Man, Thomas Mann's Doktor Faustus or Marcel Proust's A la recherche du temps perdu.

These are all canonical representatives of modernism, but this trend is equally prominent in less canonical works, such as the collection of stories, Sheherazade, of Literatuur als Losprijs (Sheherazade, or Literature as Ransom - the work has not been translated into English; 1933), by the Belgian writer Raymond Brulez. From a bibliographical point of view, the work is remarkable because the author kept all of his manuscripts, which are now held at the Flemish literary archive in Antwerp (Letterenhuis B917/H2-H3). Moreover, it is a work that thematizes the writing process. Literature is seen as a ransom a writer needs to pay to be released from the urge to tell that holds him captive. In Brulez's variation on the theme of the Arabian Nights, Sheherazade stands for the urge to tell, the obligation to express, the creative impulse and the nature of inspiration in literature. The collection consists of a frame story, focusing on a twentieth-century Sheherazade, followed by six stories. The frame story suggests that the six stories are not just told but written down by Sheherazade as a punishment for having tried to kill the sultan, Shiriar. She is probably the only Sheherazade in the tradition of the Arabian Nights who has a notebook.

Since the creative impulse is the main theme, it is no wonder that Brulez also kept a record of the moment of inspiration that sparked the idea for his collection of stories. He went to a concert in Ostend, where they played Rimsky-Korsakov's symphonic suite Sheherazade. In the concert programme, Brulez marked the 
summary of 1001 Nights and in his notes he explicitly marked the date (16 August 1929) and the occasion of what he calls the 'first thought' ('Eerste Gedacht') for this collection of stories (B917/H3). Each of the stories criticizes an ideology, suggesting that any ideology has a diabolic downside. In the ideology-ridden 1930s, Brulez's modest plea to try and be ideology-free was a brave and nonconformist statement.

One of these stories, called 'The Revolution of the Footnotes' ('De Opstand der Voetnota's), is about the production process of a book on 'Types of Government Throughout the Ages' (Regeeringsvormen door de Eeuwen heen). One of the types of government discussed in this fictitious volume is 'Monarchy' ('DE MONARCHIE'). The book is in the process of being typeset at the printer's and one night the footnotes on this page, fed up with the way they are being treated at the bottom of the page, decide to revolt and mingle with the letters in the larger font size of the body of the text. The result is that, overnight, the page that was set under the title ' $\mathrm{DE}$ MONARCHIE' turns into a mingling of letters in different font sizes, headed by the title 'anARCHIE' (Fig. 1).

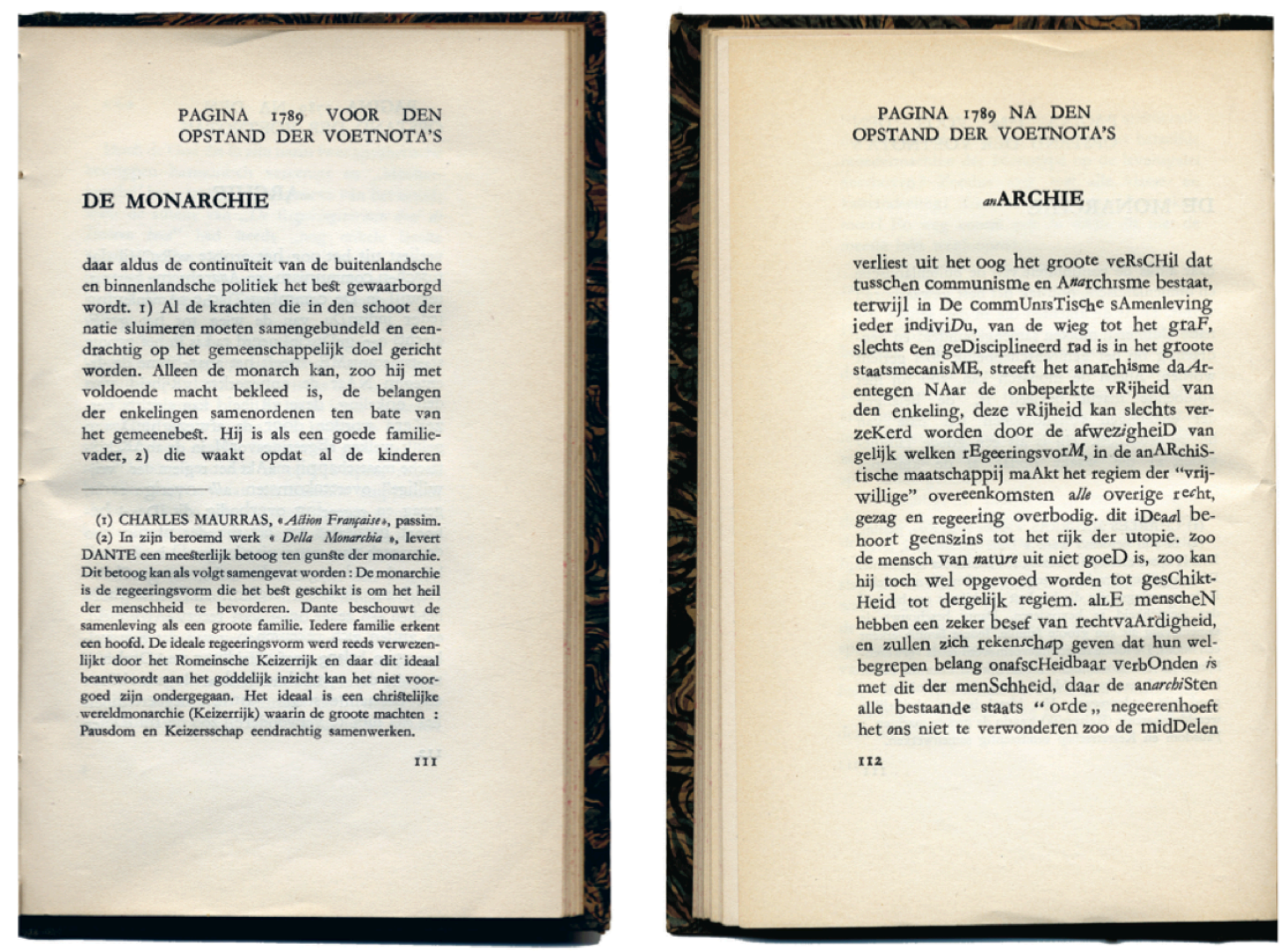

Fig. 1: Two central pages of the story 'The Revolution of the Footnotes' by Raymond Brulez in the 1946 edition by De Nederlandsche Boekhandel. 
These two pages are the centre of the story. They represent the process of the battle, so to speak, before and after the revolution. Around these two central pages, Brulez first wrote two pages of introduction and rising action, and then two pages with the catastrophe and the dénouement. The text of the central pages - hereafter referred to as MONARCHY and anARCHY - was first handwritten and later typed out. Initially, Brulez tried to use every letter of the MONARCHY text to write the anARCHY text, so he started crossing out letters in colour crayon. But that turned out to be too ambitious, so in the end he just made sure that all the capital letters and letters in italics were present in both versions. Then he made some calculations and lists of letters to prepare a second typescript.

While Brulez was drafting his story, he made a sketch to visualize the juxtaposition of the page before the revolution ('DE MONARCHIE') and the same page after the revolution ('anARCHIE') (Fig. 2).

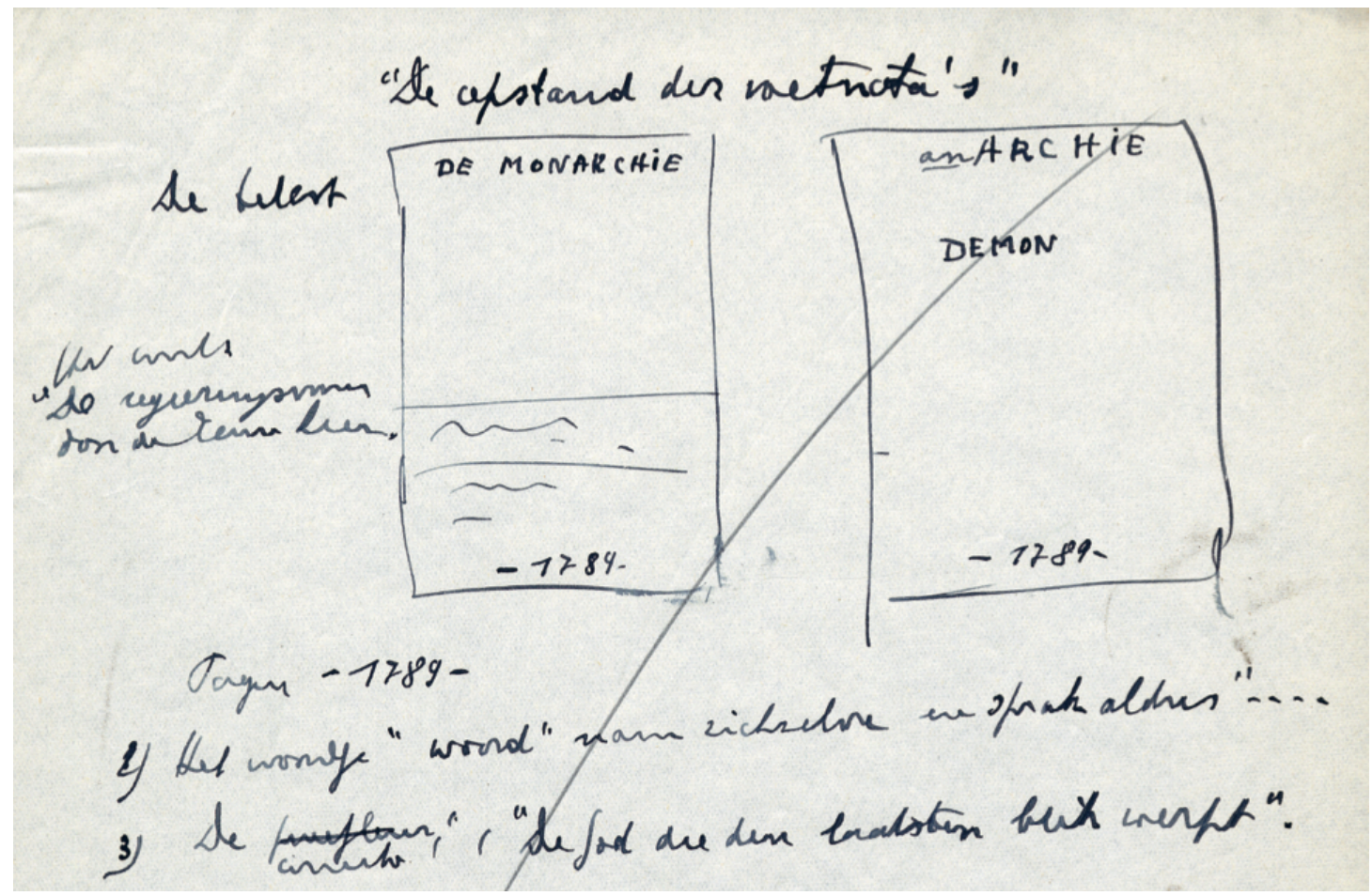

Fig. 2: Sketch by Raymond Brulez visualizing the juxtaposition of the page before the revolution ('DE MONARCHIE') and the same page after the revolution ('anARCHIE'), Letterenhuis B917/H3.

The basic idea was that the first five capital letters 'DE MON' of the title 'DE MONARCHIE' would have to be present in the text of 'anARCHIE'. In this way, Brulez subtly suggested that there is a 'demonic' aspect to every ideology, be it 
monarchy or anarchy. When the story was published separately in the Flemish, catholic journal Hooger Leven (8 January 1933) and later in the Dutch magazine De Groene Amsterdammer (1 February 1936), the typesetters took the trouble to make sure that the letters $\mathrm{D}, \mathrm{E}, \mathrm{M}, \mathrm{O}$ and $\mathrm{N}$ did feature somewhere in the text of the 'anARCHIE' page.${ }^{17}$ But in the editions of the collection as whole, quite a few things went wrong.

The irony of this story about a 'revolution' of footnotes during the process of a book's typesetting is that the story was left out of the first edition (1933) of Sheherazade because the typesetting was too challenging according to the publisher. ${ }^{18}$ Not until 1946, when a new edition was published by De Nederlandsche Boekhandel, was the story integrated in the collection. The format of this edition is quite small. To make the text of the two central pages (MONARCHY and anARCHY) fit the format, a three-line passage from the anarchy text was cut. As it happens, of the five capital letters $\mathrm{D}, \mathrm{E}, \mathrm{M}, \mathrm{O}$ and $\mathrm{N}$, the capital $\mathrm{O}$ disappeared because of this cut and, as a consequence, so did the 'DEMON'. What is worse is that the 1946 edition was chosen as copy text when a new edition was established in 1999, even though the latter's format was larger and there was consequently no intrinsic reason not to restore the cut passage. ${ }^{19}$ In defence of this neglect, one could probably argue that Brulez's typographical criticism of ideology was so subtle that, in the chaos of font sizes in the 'anARCHIE' text, very few readers would have recognized the DEMON anyway. But even if anyone would be able to prove that Raymond Brulez (explicitly or silently) approved the omission of the three lines - which would have reduced the 'DEMON' sketch to a vestigial note - the note does play an integral role in the story's genesis. It offers valuable information in terms of the genetic dossier's hermeneutic potential as it draws our attention to the author's creative use of typography to make a political and philosophical point that was quite relevant in the story's historical context and still is today. Sheherazade would therefore be well served by 'new modernist editing' in the form of a digital genetic edition.

In the manuscript of the frame story ('Wat is liefde zonder verleiding?' / 'What Is Love without Seduction?'), Brulez initially wrote without any elaboration that Sheherazade had written the stories, focussing directly on the product rather than the process: 'Ze heeft de verhalen opgeschreven.' (She has written the stories; B917/H3 f. 19r) But then he cancelled the sentence and started to describe the creative process, noting that it is only seemingly easy to fill a notebook with one's phantasy. ${ }^{20}$ 
And on the next page, in free indirect speech, he made Sheherazade wonder what 'for heaven's sake' she was going to tell ('Wat moest ze in 's hemels naam gaan vertellen?' f. 20r). This question is followed by a few blank lines in which the blankness of her mind seems to be enacted.

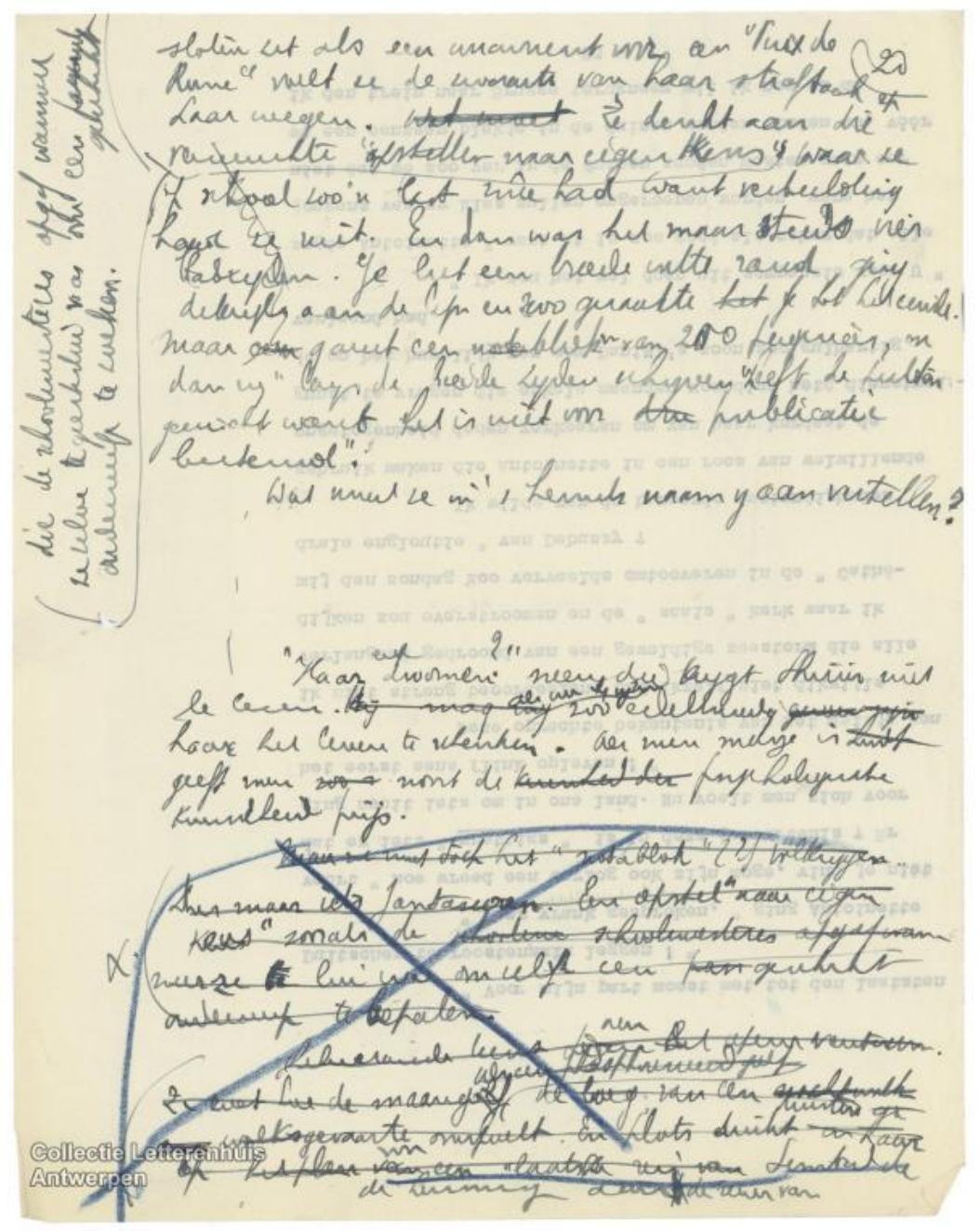

Fig. 3: Manuscript of 'Wat is liefde zonder verleiding', f. 20r, Letterenhuis B917/H2a

After this blank space, Brulez makes her wonder whether she should tell Shiriar her dreams, but she immediately decides against it: 'Her dreams? No, those are not to be read by Shiriar.' ('Haar droomen? Nee, die krijgt Shiriar niet te lezen'; f. 20r). And then, in a passage that is deleted in blue crayon, Brulez thematizes what Samuel Beckett would later call 'the obligation to express' ${ }^{21}$ The first line of this deleted passage reads: 'Still, she needed to fill this notebook (?).' ('Maar ze moest toch het "notablok" (?) volkrijgen.' f. 20r; author's question mark). In other words, the obligation to express, the inner urge to tell as the core engine driving literary creativity, is presented as a very concrete pensum: the task of filling a notebook. 
The last story of the collection is about Hercules who is at a crossroads. He can choose the path of Virtue or the path of Vice. He chooses the first, but this journey ends with disillusion. The notebook is complete, but here the sultan suddenly intervenes. He is not satisfied with this ending and demands another one. She is to write on the cover, and so she makes Hercules choose the path of Vice. When the cover is full, she reaches the end. This ending, however, is equally unsatisfactory. Shiriar demands her to take the last page, turn it ninety degrees and write across the lines 'the way lovers do when they do not find enough space for the thousands of kisses to close their love letter' ('zoals verliefden doen, die op hun brief geen plaats meer vinden voor de duizenden kussen van de afscheidsfinale'). ${ }^{22}$ And then Brulez and Sheherazade write the third ending, which is reminiscent of Nietzsche's Beyond Good and Evil. ${ }^{23}$ Brulez' interpretation of Nietzsche implies that not to choose is a choice, too. In the context of Brulez' critique of ideology, the individual's choice not to belong to any group or '-ism' (be it communism, fascism or anarchism) was an important statement in 1930s literature. And again, like his more famous modernist colleagues, Brulez chose to present this content in a form that thematises the writing process, linking the fictional world to the manuscripts.

\section{Late Modernism}

This close link between the fictional world and the manuscripts becomes possibly even more conspicuous in late modernism. In Samuel Beckett's novel Malone meurt / Malone Dies, there is a particularly close autographic link between the writer and the protagonist, writing with his pencil in his exercise book. The work was written in French. In the first manuscript, the first paragraph ends with an autographic moment in Abbott's sense of a 'mode of action taken in the moment of writing'. ${ }^{24}$ Wishing everyone an atrocious life, Malone ends his pensum for the day: 'Je m'arrête Assez pour ce soir' (BDMP5, FN1, 52r) (I stop ${ }^{\text {Enough }}$ for this evening). Here, not just Malone but also Beckett had enough for 'this evening', which in Beckett's case was the evening of 27 November 1947.25

In the last novel of the so-called 'trilogy', L'Innommable, this autographic link between the content and the material object is extraordinary. While, in Brulez's work, Sheherazade's notebook stood for the 'ransom' or the pensum that is literature, the same idea becomes palpable in the manuscript of L'Innommable, consisting of two notebooks. From the point of view of cognitive philosophy, one could argue that, in 
these notebooks, Beckett's work enacts the enactive mind at work. ${ }^{26}$ If, as a late modernist writer, one wishes to show the process of 'writing as thinking', or 'thinking on paper', the evocation of the fictional mind would logically have to stop when there is no more paper. That is exactly what happens in the manuscript of L'Innommable. The materiality of the notebook was such an important part of Beckett's model of the mind that he decided to end his novel on the very last page of his second notebook. The words 'il faut continuer, je vais continuer', followed by 'FIN' and the place and date ('Ussy janvier 1950') are written on the very last page (the verso of the back flyleaf) of the second notebook, so there was no space left to continue. ${ }^{27}$ For a novel of more than 260 pages (in the first Minuit edition), ${ }^{28}$ this is either an extraordinary coincidence, or - more likely - a conscious decision. From a hermeneutic perspective, it may seem strange to focus on such material, bibliographic details, but these details tell us a great deal about the author's poetics. They indicate that the tension between the word 'on' (as in 'go on', Beckett's translation of 'continuer') and the impossibility to go on ('FIN') is crucial, not just in terms of the content of Beckett's works.

These bibliographical and genetic phenomena actually enact the Beckettian concept of going 'on', for the end had already been written much earlier, which was exceptional for Beckett. The manuscript consists of two notebooks. After about twenty pages into the first notebook, relatively early in the writing process, Beckett had an idea for the ending. On 1 June 1949, he wrote to Georges Duthuit:

I have done a little work. Each time I get down to it, it comes fairly easily, but I am reluctant to get down to it, more than ever. I have done one thing that I had never happened to do before: I wrote the last page of the book I am working on, whereas I am only on my 30th. I am not proud of myself. But the outcome is already so little in doubt, whatever the writhings that lie between me and it, of which I have only the vaguest of ideas. ${ }^{29}$

Beckett told Duthuit he was not proud of himself, probably because writing the end at the beginning was something he associated with writing à la Balzac and, from Beckett's perspective, Balzac had always served as the bad example, one he used in his lectures when he was teaching French literature at TCD in the early 1930s. Nonetheless, in the case of L'Innommable, he did write what - at that point - he thought of as 'the last page' at an early stage of the writing process. He wrote it on 
two separate sheets which he then pasted into the back of the first notebook, possibly presuming that he would only need one notebook to finish his novel. Eventually, it turned out that he needed a second notebook. And the text of what he had conceived of as 'the last page' was later incorporated in a passage that corresponds with page $53 \mathrm{v}$ of the second notebook, close to, but not quite the end. Instead, he kept writing until there was no more space in the notebook. As indicated above, for a 260-page novel, it is very unlikely that the end just 'happened' to coincide with the last page of the notebook. It is more likely that Beckett saw it as his pensum to fill the notebook to the brim, until the very last page (the back flyleaf). He kept on writing and made his narrator go on until the materiality of the notebook prevented him from doing so. And where he could not go on, he wrote: 'Je vais continuer' ('I'll go on'), expressing a dysteleological aesthetic in which any 'telos' is constantly being questioned and which requires a documentary editorial approach in addition to a teleological one.

Recently, this double perspective was introduced in the genetic scholarly edition of the Beckett Digital Manuscript Project, which tries to digitally reunite all the extant manuscripts by Samuel Beckett. Initially, the main entry point for the edition was the button 'genetic editions', offering a drop-down menu with a list of published works by Beckett (the 'Beckett canon'). In addition to this teleological approach the edition now offers a less teleological way into the materials, on the one hand via the 'Beckett Digital Library' and on the other hand via the 'Notebooks'. ${ }^{30}$

One of the most precious notebooks in Beckett studies is the so-called 'Whoroscope' Notebook (called after the word that is written on its front cover, preserved at the University of Reading, UoR MS 3000). It contains conceptual notes for Beckett's novel Murphy; pasted clippings from newspapers (as in a commonplace book); jottings (such as German phrases, which he picked up during his six-month stay in Germany); quotations and excerpts. For instance, in a cluster of three excerpts from Lemprière's Classical Dictionary of Proper Names, there is a long note on Sisyphus (UoR MS 3000, 32r). He had been so fascinated by Goethe's poem 'Prometheus' that he had typed it out and started reading Dichtung und Wahrheit, in which Goethe explains that he was drawn to the Prometheus myth:

The Titans are the foil of polytheism, as the Devil may be considered the foil of monotheism; though, like the only God to whom he stands in contrast, he is not a poetic figure. The Satan of Milton, though boldly enough drawn, still 
remains in the disadvantageous light of a subordinate existence, attempting to destroy the splendid creation of a higher being: Prometheus, on the contrary, has this advantage, that, even in spite of superior beings, he is able to act and to create. ${ }^{31}$

But Goethe was quick to add that, in general, he was more drawn to heroes of peaceful, patient opposition and that, for that reason, he regarded Tantalus, Ixion and Sysiphus as his 'saints'. ${ }^{32}$ After reading Goethe, Beckett looked up the entries on Ixion, Sisyphus and Tantalus in Lemprière's Classical Dictionary and copied the long excerpts in his 'Whoroscope' Notebook (UoR MS 3000, 31r-33r), shortly before he went to Germany (the date 'Germany 2/10/36' is marked on page 33v, at the back of the Tantalus entry).

While Beckett was in Germany, he jotted down the note 'a glass of Wallenstein's Lager' (36r), which is the beer that Moran drinks in the novel Molloy. ${ }^{33}$ If one looks only for notes - like this one - that made it directly into Beckett's works, the result is rather meagre. In a teleologically modelled edition, a textual note to the text of Molloy might refer readers to the note 'a glass of Wallenstein's lager' in the 'Whoroscope' Notebook. Additionally, however, I believe it is a task of 'new modernist editing' to present the 'Whoroscope' Notebook from a dysteleological perspective, enabling readers to investigate also the 'vestigial' notes, as they show the author's profound interest in German art and literature as part of his developing poetics. Beckett grew up with Shakespeare and the King James Bible in an Anglophone society; he studied Dante and Italian literature at Trinity College Dublin; he taught French literature as a lecturer. But his autodidactic explorations of German culture arguably had at least as great an impact on his poetics as the other three languages and cultures.

One last example may illustrate the relevance of a 'vestigial' note to the study of an author's poetics. Beckett read a German book on Der Pessimismus by Olga Plümacher, one of the most heavily annotated books in Beckett's library. ${ }^{34}$ To explain the notion of pessimism, Plümacher alludes to Leibniz's claim that this is the best of all possible worlds. This theodicy, she writes, is hanging from the very thin string of the religious dogma of an omniscient and omnipotent creator and even the optimists' praise of the world is always blemished by a sense of 'in spite of everything' (trotz alledem und alledem).$^{35}$ For this reason, she proposes to replace the static superlative 
'Optimismus' by the more dynamic comparative 'Meliorismus', suggesting that, by interfering in natural processes, human beings can bring about progress and improvements over the natural state of things. On the facing page, Beckett pencilled the neologism 'Pejorismus', which would be the opposite philosophy, holding that humanity is nothing to be boasting about since human interference can bring about serious regress vis-à-vis the natural processes. ${ }^{36}$ In addition to these marginalia, Beckett also jotted down the terms 'meliorism / pejorism' in his 'Whoroscope' Notebook (UoR MS 3000, 45v). They were not crossed out or otherwise marked as usable material for any of his drafts, but that does not mean that these vestigial notes did not contribute to Beckett's work. They are in fact crucial notions to understand his developing poetics in this pivotal period of his career, just before the Second World War. The hypothesis that our world might be the worst rather than the best of all possible worlds may lead to a static pessimism. Beckett's 'pejorism' is more dynamic, but it does not imply progress, nor necessarily regress. He preferred the word 'gress' or 'mere gress', as he called it, because of its 'purity from destination and hence from schedule' (LSB I 186) - in other words a non-teleological or dysteleological view.

\section{Conclusion}

What the less teleological editorial model shows is that, from the writer's point of view, the 'work' was not only a canon of published texts, but also a set of writings in a continuum. Autography implies seeing literature from the writer's perspective as a continuous effort of writing rather than a set of tasks to finish books by a deadline to cater for the publisher. Since every writer has his or her own way of writing drafts and making notes, a digital edition will need to fine-tune the typology of notes accordingly for each author, but the point is that the literary work is presented as more than only a set of finished products. What the model combining the teleological and the less teleological approaches shows is that a modernist oeuvre is often a form of 'autopoiesis' (from the Greek, meaning 'self-creation', 'self-production'). In biology, this term (introduced in 1972 by the Chilean biologists Humberto Maturana and Francisco Varela) refers to a system capable of reproducing and maintaining itself. Jerome McGann has applied this to texts, which he sees as 'autopoietic mechanisms operating as self-generating feedback systems that cannot be separated from those who manipulate and use them' ${ }^{37}$ At least one aspect of this autopoiesis is genetic in nature. When an author is writing a text, there is a constant feedback loop with his or 
her previous works, especially if $\mathrm{s} / \mathrm{he}$ is reminded of them through broadcasts, productions and journal publications. As a result, if literary texts can be regarded as autopoietic mechanisms, it seems crucial to see these texts not so much (or not exclusively) in terms of a 'complete works' edition but also in terms of a 'complete writings' edition. Such an edition would entail not just the author's canon, but also the unfinished scraps, disjecta, odds and ends, the notebooks, the interaction with older work through translation, theatre productions or journal publications. It is this interaction, often materialized in the writer's notebooks, that constitutes the driving force of the self-generating feedback system that is an author's work. In that sense, Sheherazade's notebook and the difficulty of completing it are emblematic of the endeavour to edit not just literary products but also the never-ending process of literary creation.

\footnotetext{
${ }^{1}$ H. Porter Abbott, Beckett Writing Beckett: The Author in the Autograph (Ithaca and London: Cornell University Press, 1996), p. x.

${ }^{2}$ Nelson Goodman, Languages of Art (Indianapolis, IN: Hackett Publishing, 1968), p. 113.

${ }^{3}$ Grésillon, Almuth, Éléments de critique génétique: Lire les manuscrits modernes (Paris: Presses universitaires de France, 1994).

${ }^{4}$ The Beckett Digital Manuscript Project (henceforth abbreviated as BDMP; www.beckettarchive.org) is a genetic edition that consists of modules. Fin de partie / Endgame is module 7. Every digital module is accompanied by a printed volume, in this case: Dirk Van Hulle and Shane Weller, The Making of Samuel Beckett's Fin de partie / Endgame (London: Bloomsbury, 2018).

${ }^{5}$ Gillian Beer, Darwin's Plots: Evolutionary Narrative in Darwin, George Eliot and NineteenthCentury Fiction (Cambridge: Cambridge University Press, 2000), p. 6.

${ }^{6}$ First transcribed by David Hayman, A First-Draft Version of Finnegans Wake (Austin: University of Texas Press, 1963), p. 64. For a more recent transcript, see also James Joyce Digital Archive (http://jjda.ie/main/JJDA/JJDAhome.htm).

${ }^{7}$ James Joyce, Finnegans Wake (London: Faber and Faber, 1939), p. 36.

${ }^{8}$ Daniel Ferrer, 'Clementis's Cap: Retroaction and Persistence in the Genetic Process', Yale French Studies 89: pp. 223-36: 'Even the definition of project [...] oscillates between an anticipatory perspective [...] and a retrospective vision that characterizes it with regard to an accomplishment.' (p. 225).

9 James Joyce, Ulysses, edited by Hans Walter Gabler with Wolfhard Steppe and Claus Melchior, London: The Bodley Head, 1986), pp. 628-9; emphasis added.

${ }^{10}$ Nelson Goodman, Languages of Art (Indianapolis: Hackett Publishing, 1968), p. 113.

${ }^{11}$ Michael Groden et al., James Joyce Archive (New York: Garland, 1978-79).

12 Joyce, Finnegans Wake, p. 112.

${ }^{13} \mathrm{http} / / / \mathrm{jj}$ da.ie/main/JJDA/JJDAhome.htm; accessed on 4 November 2018.

${ }^{14}$ Dirk Van Hulle, 'Editing the Wake's Genesis: Digital Genetic Criticism', in James Joyce and Genetic Criticism: Genesic Fields. European Joyce Studies 28 (Leiden: Brill, 2018), pp. 37-54.

15 'Work in Progress' was the title of many of the pre-book publications of Finnegans Wake fragments. James Atherton, The Books at the Wake: A Study of Literary Allusions in James Joyce's Finnegans Wake (London: Faber and Faber, 1959), p. 59.

${ }^{16}$ Charlotte Guichard, 'L'histoire de l'art à l'épreuve de la critique génétique. La main dans la peinture des Lumières', paper delivered at the Colloque du Cinquantenaire 'Critique génétique comme processus', 17-20 October 2018, ENS, Paris.
} 
${ }^{17}$ Raymond Brulez, 'De Opstand der Voetnota's', Hooger Leven 7.2 (8 January 1933), p. 50; 'Opstand der Voetnoten', De Groene Amsterdammer Jg. 60, nr. 3061 (1 February 1936), p. 18.

${ }^{18}$ See Raymond Brulez, De Toren van Lynkeus (Bruges: Desclée De Brouwer, 1969), p. 66.

${ }^{19}$ In 2015, Houtekiet published a new edition that did restore the three cut lines.

${ }^{20}$ Raymond Brulez, Sheherazade of Literatuur als losprijs (Antwerpen: Houtekiet, 2015), p. 22: 'Bij het eerste zicht schijnt het maar een kleintje om zo'n blocnote vol te fantaseren. Maar nu ze tussen de naakte wanden van haar kamertje opgesloten zit als een concurrent voor een "Prix de Rome" voelt Sheherazade de volle zwaarte van de straf op haar wegen.'

${ }^{21}$ Samuel Beckett, Proust and Three Dialogues with Georges Duthuit (London: John Calder, 1999), p. 103.

${ }^{22}$ Raymond Brulez, Sheherazade of Literatuur als losprijs (Antwerpen: Houtekiet, 2015), p. 127.

${ }^{23}$ In terms of exogenetic material, there is an interesting note referring to 'Nietzsche's / (...) ewige Wiederkehr' (B917/H3) among the notes for one of the other stories, 'Sindbad's Eighth Journey, or: "Happiness Is the Other..." ('De achtste reis van Sindbad of "Het Geluk is het andere..."').

${ }^{24}$ H. Porter Abbott, Beckett Writing Beckett: The Author in the Autograph (Ithaca and London: Cornell University Press, 1996), p. x.

${ }^{25}$ Dirk Van Hulle and Pim Verhulst, The Making of Samuel Beckett's Malone meurt / Malone Dies (London: Bloomsbury, 2017), pp. 123-24.

${ }^{26}$ Enactivism is an umbrella term for a number of late 20th-century post-Cartesian cognitive theories that reject the strict mind/world divide and claim instead that the mind continuously shapes and is shaped by its material environment. See Varela, Thompson and Rosch 1991, Clark and Chalmers 1998, Menary 2007, Hutto and Myin 2013. Andy Clark and David Chalmers. 2010 [1998], 'The Extended Mind', in: The Extended Mind, edited by Richard Menary (Cambridge, MA: The MIT Press), 27-42. Francisco J. Varela, Evan Thompson, and Eleonor Rosch, The Embodied Mind: Cognitive Science and Human Experience (Cambridge, MA: The MIT Press, 1991); Richard Menary, Cognitive Integration. Mind and Cognition Unbounded (London: Palgrave Macmillan, 2007). Daniel D. Hutto and Erik Myin, Radicalizing Enactivism. Basic Minds without Content (Cambridge, MA: The MIT Press, 2013).

${ }^{27}$ Dirk Van Hulle and Shane Weller, The Making of Samuel Beckett's L'Innommable / The Unnamable (London: Bloomsbury, 2014), p. 177.

${ }^{28}$ Samuel Beckett, L'Innommable (Paris: Les Éditions de Minuit, 1953).

${ }^{29}$ Samuel Beckett, The Letters of Samuel Beckett: vol. 2, 1941-1956, edited by George Craig, Martha Dow Fehsenfeld, Dan Gunn, Lois More Overbeck (Cambridge: Cambridge University Press, 2011), p. 162; emphasis added.

${ }^{30}$ The Beckett Digital Manuscript Project, www.beckettarchive.org

${ }^{31}$ Johann Wolfgang von Goethe, 'Autobiography: Truth and Fiction Relating to My Life', The Works of Johann Wolfgang von Goethe, vol. 2 (London, New York and Chicago: The Anthological Society, 1901), pp. 211-212.

${ }^{32}$ Goethe, 'Autobiography', p. 212: 'the Titanic, gigantic, heaven-storming character afforded no suitable material for my poetic art. It better suited me to represent that peaceful, plastic, and always patient, opposition, which, recognizing the superior power, still presumes to claim equality.' Cf. Goethe, Aus meinem Leben: Dichtung und Wahrheit (Tübingen: Cotta, 1814) 3: p. 479.

${ }^{33}$ Samuel Beckett, Molloy (Paris: Les Éditions de Minuit, 1951), p. 150.

${ }^{34}$ See Beckett Digital Library (BDL), http://www.beckettarchive.org/library/PLU-PES.html

${ }^{35}$ Olga Plümacher, Der Pessimismus in Vergangenheit und Gegenwart: Geschichtliches und Kritisches (Heidelberg: Georg Weiss Verlag, 1988), p. 2.

${ }^{36}$ For a discussion of the impact of this reading on the development of Beckett's poetics, see Dirk Van Hulle, 'Negative Modernism: Beckett's Poetics of Pejorism and Literary Enactment', in: Beckett and Modernism, edited by Olga Beloborodova, Dirk Van Hulle and Pim Verhulst (London: Palgrave Macmillan, 2018), pp. 1-18.

${ }^{37}$ Jerome McGann, The Textual Condition (Princeton, NJ: Princeton University Press, 1991), p. 15. 